\title{
Effect of Lavandula dentata extract on Ovalbumin-induced Asthma in Male Guinea Pigs
}

\author{
Z. N. Almohawes ${ }^{a *}$ (D) and H. S. Alruhaimi ${ }^{a}$ \\ aDepartment of Biology, Faculty of Science, Princess Nourah bint Abdulrahman University, Riyadh, \\ Kingdom of Saudi Arabia \\ *e-mail: znalmohawes@pnu.edu.sa,drzakilogy@hotmail.com
}

Received: February 13, 2018 - Accepted: July 24, 2018 - Distributed: February 28, 2020

\begin{abstract}
Asthma is an inflammatory disease of the lungs, and it causes oxidative stress. Lavandula dentata is an aromatic herb with anti-oxidative and anti-inflammatory activities. This study examined the activity of $L$. dentata extract on a guinea pig model of asthma. Adult males were divided into five groups: First group was control, second was asthma model induced by OVA, third was treated with L. dentata extract orally ( $300 \mathrm{mg} / \mathrm{kg}$ ) for 21 days; the fourth was an asthma model with $L$. dentata extract $(300 \mathrm{mg} / \mathrm{kg})$ and fifth was treated with Tween 80 for 21 days. OVA treatment increased IgE, triglycerides, total cholesterol, glucose levels in serum, WBC count in blood and MDA in lungs. Also, OVA reduced SOD activity, GSH content in lungs, and GGT activity in serum $(\mathrm{p}<0.05)$. L. dentata extract treatment in asthma model reduced elevated IgE, triglycerides, total cholesterol, glucose levels in serum, and MDA in lungs $(p<0.05)$, while it increased GSH content in lungs $(p<0.05)$. These results suggest the possibility that $L$. dentata extract can exert suppressive effects on asthma, and may provide evidence that it is a useful agent for the treatment of allergic airway disease, it also limits oxidative stress induced by OVA. L. dentata extract appears to have hypolipidemic and hypoglycemic activities.
\end{abstract}

Keywords: Lavandula dentata, ovalbumin, asthma, antioxidant, lipid peroxidation.

\section{Efeito do extrato de Lavandula dentata na asma induzida por ovalbumina em cobaias machos}

\begin{abstract}
Resumo
A asma é uma doença inflamatória dos pulmões e causa estresse oxidativo. Lavandula dentata é uma erva aromática com atividades anti-oxidantes e antiinflamatórias. Este estudo examinou a atividade do extrato de L. dentata em um modelo de asma de cobaia. Os machos adultos foram divididos em cinco grupos: o primeiro grupo foi controle, o segundo modelo foi o da asma induzido pela OVA, o terceiro foi tratado com extrato de L. dentata por via oral (300 mg / kg) por 21 dias; o quarto foi um modelo de asma com extrato de L. dentata (300 mg / kg) e o quinto foi tratado com Tween 80 por 21 dias. O tratamento com OVA aumentou a IgE, os triglicerídeos, o colesterol total, os níveis de glicose no soro, a contagem de leucócitos no sangue e o MDA nos pulmões. Além disso, o OVA reduziu a atividade da SOD, o conteúdo de GSH nos pulmões e a atividade da GGT no soro $(\mathrm{p}<0,05)$. O tratamento com extrato de L. dentata no modelo de asma reduziu a IgE elevada, triglicérides, colesterol total, níveis séricos de glicose e MDA nos pulmões $(\mathrm{p}<0,05)$, enquanto aumentou o conteúdo de GSH nos pulmões $(\mathrm{p}<0,05)$. Estes resultados sugerem a possibilidade do extrato de L. dentata poder exercer efeitos supressores sobre a asma, e pode fornecer evidências de que é um agente útil para o tratamento de doenças alérgicas das vias aéreas, além de limitar o estresse oxidativo induzido pela OVA. $\mathrm{O}$ extrato de L. dentata parece ter atividades hipolipemiantes e hipoglicêmicas.
\end{abstract}

Palavras-chave: Lavandula dentata, ovalbumina, asma, antioxidante, peroxidação lipídica.

\section{Introduction}

Asthma is a chronic disease defined by variable features, including reversible airways obstruction, airway responsiveness and inflammation. In 2014, it affected around 300 million people worldwide (GINA, 2014). The risk of developing asthma is enhanced by exposure to inhaled pollutants such as allergens, viruses, bacteria, fungi, tobacco smoke and ozone, which initiate allergic symptoms (Holgate 2008; Selgrade et al., 2013). Oxidative stress plays a critical role in asthma pathogenesis. Several reports have demonstrated that oxidative stress is a crucial consequence of asthma inflammatory response (Nadeem et al., 2008; Wood et al., 2003). Lymphocytes, macrophages and other cell types 
participate in the increased production of reactive oxygen species (ROS) in asthma, which may initiate and enhance airway inflammation and alteration of antioxidant defense systems such as glutathione(GSH), superoxide dismutases (SOD), catalase(CAT) and glutathione peroxidases(GPx), and thus leads to pathophysiological effects associated with asthma such as mucus hypersecretion, vascular permeability, epithelial shedding and smooth muscle contraction (Nadeem et al., 2008). The potential injury of ROS can be reduced by a number of antioxidants, these could be exogenous antioxidants acquired from diet such as tocopherols, carotenoids, flavonoids and ascorbate, or endogenous including antioxidant enzymes (SOD, GPx, and CAT), thiols (GSH) and metal-binding proteins (lactoferrin, transferrin, ceruloplasmin), therefore, the use of antioxidants to maintain the oxidant-antioxidant balance might be effective in the management of asthma (Kirkham and Rahman 2006).

Asthma induced by Ovalbumin (OVA) is known as a disease that is the result of chronic airway inflammation usually related with infiltration of lymphocytes, eosinophils, and neutrophils into bronchial lumen, with an increase of reactive nitrogen and oxygen species levels (Roh et al., 2008). Recently, several researches proved that oxidative stress is one of the important determinants of asthma, therefore, the use of natural compounds that have an antioxidant and anti-inflammatory activity might be a useful therapeutic approach.

Medicinal plants are a major source for antioxidants, the antioxidant action of numerous extracts from medicinal herbs has been broadly documented in vitro and vivo studies. Lavandula dentata. (Lamiaceae), commonly known in Saudi Arabia as "Dhurm", is a widely distributed aromatic herb (Rahman et al., 2004). Lavandula angustifolia is known as a powerful aromatic and medicinal herb. It is used in traditional and folk medicines in various parts of the world for treating gastrointestinal, nervous and rheumatic ailments (Duke, 1989; Evans, 1989; Leung and Foster, 1996). Pharmacological and biological studies of lavender (extracts, fractions, and essential oil) reported that it has anti-convulsive, sedative, spasmolytic, local anaesthetic, antioxidant, anti-bacterial and mast cell degranulation inhibitory effects (Ghelardini et al., 1999; Gilani et al., 2000; Hohmann et al., 1999; Kim and Cho, 1999; Leung and Foster, 1996; Lis-Balchin and Hart, 1999; Maruyama et al., 2005; Yang et al., 2010). Phytochemical researches showed that linalool, linalyl acetate and additional mono and sesquiterpenes, flavonoids such as luteolin, triterpenoids like ursolic acid and coumarins such as umbelliferone and coumarin were the primary constituents of the aerial parts and flowers of lavender plant (Duke, 1989; Leung and Foster, 1996; Omidbaigi, 2000; Renaud et al., 2001). L. angustifolia protected the neurons from glutamate toxicity (Büyükokuroğlu et al., 2003). L. dentata decreased blood sugar levels (Gamez et al., 1987), and also has anticancer properties (Ali et al., 2015; Vijaya et al., 2009), anti-inflammatory, analgesic activities (Algieri et al., 2016; Hajhashemi et al., 2003; Silva et al.,
2015), helpful for urine retention, removal of kidney and urethral stones (Rahman et al., 2004), antioxidant and antifungal (López et al., 2007), wound healing, rheumatic, urine retention, kidney stones, antiseptic (Rahman et al., 2004), and antiprotozoal (Al-Musayeib et al., 2012).

This study investigates potent anti-asthmatic and antioxidant activity of $L$. dentata extract against OVA induced asthma in Guinea pigs. It was based on a hypothesis that its extract has an antioxidant effect on allergic asthma in Guinea pigs model. The use of Lavendula dentata extract is an attempt to ameliorate asthma attacks and their effects as well as increasing the body's defenses against asthma.

\section{Materials and Methods}

\subsection{Plant material and preparation of the extract}

Lavendula dentata plant was collected from Taif in the west part of Saudi Arabia. plant was identified by the Plants Taxonomy and Herbarium Unit, Faculty of Pharmacy, King Saud University, Riyadh, the voucher specimens (NO.15112) have been deposited at the Herbarium of the Faculty of Pharmacy, King Saud University, Riyadh, Saudi Arabia. The extraction of the flowers and leaves of the plant was done by the Department of Pharmacognosy and Research Center of Medicinal and Aromatic Plants in the Pharmacy Faculty of King Saud University in Riyadh. It was dissolved in Tween 80 , and it was given $(300 \mathrm{mg} / \mathrm{kg})$ (Bhatia et al., 2008) orally for 21 days.

\subsection{Animals}

Adult male guinea pigs Cavia procellus weighing 500-700 g were obtained from the Animal Care Center, College of Pharmacy (King Saud University, Riyadh, Saudi Arabia). They were housed in pairs per cage at $22-24^{\circ} \mathrm{C}$ with a $12 \mathrm{~h}$ light, $12 \mathrm{~h}$ dark. The animals were acclimatized in house conditions for a week prior. The study protocol was approved by the Research Ethics Committee of the College of Pharmacy (King Saud University, Riyadh, Saudi Arabia).

\subsection{Ovalbumin (OVA) sensitization and challenge}

Guinea pigs were sensitized with OVA as described by (Misaka et al., 2009), animals were immunized on days 0,7 , and 14 via intraperitoneal injection of $0.1 \mathrm{mg}$ chicken OVA (Grade III; sigma-Aldrich), emulsified in $1 \mathrm{mg}$ of aluminum hydroxide (sigma-Aldrich) as an adjuvant, according to (Park et al., 2007), both were dissolved in $0.5 \mathrm{ml}$ normal saline. On day 21, 22, 23 of the experiment, guinea pigs were challenged by Aerosolizing them with $1 \mathrm{mg} / \mathrm{ml}$ of OVA. Aerosolizing was performed for $15 \mathrm{~min}$ by placing the animal in a chamber connected to a nebulizer, according to (Muraki et al., 2008)

\subsection{Experimental design}

Guinea pigs were divided randomly into five groups (5 guinea pigs each), group 1: Control; group 2: Asthma model; group 3: Treated orally with $L$. dentata extract (300 mg/kg) for 21 days; group 4: Asthma model with 
L. dentata extract orally $(300 \mathrm{mg} / \mathrm{kg}$ ) starting from day 3 to 23 OVA+EXT; group 5: Treated with Tween 80 for 21 days.

\subsection{Blood Collection}

24 hours after the challenge, rats were anesthetized (each animal was made to fast for 12 hours before anesthetization) by intraperitoneal injection of Ketamine $(50 \mathrm{mg} / \mathrm{kg})$ and Rompun (20mg/kg) (Elovsson et al., 2005). Blood samples were withdrawn from the heart via Cardiac Puncture. Samples were centrifuged at $3000 \mathrm{rpm}$ for separation of sera that were stored at $-20^{\circ} \mathrm{C}$ until assayed. Serum samples were assayed for Measurement of Immunoglobulin (Ig) G and E, triglycerides, total cholesterol, total protein, albumin, globulin content creatinine, urea concentration, glucose level, Alanine aminotransferase (ALT), Aspartate aminotransferase (AST), gamma-glutamyl-transferase (GGT) and lactate dehydrogenase (LDH) activity, using commercial available assay kit (Biomerieux) according to manufacturer instruction.

\subsection{Hematological assay}

Counting red blood cells (RBC), White blood cells (WBC), Blood platelets (PLT), Hemoglobin content (Hgb), Haematocrit value (Hct) determined by using Vet-Animal Blood counter (ABC) (ABX-France).

\subsection{Biochemical assays in lung homogenate}

Samples were dissected from the right lung and washed immediately with ice cold saline to remove as much blood as possible, then the lungs were weighed to prepare the homogenate. The tissue was homogenized with ice-cold $0.25 \mathrm{M}$ sucrose in Tris $\mathrm{HCl}$ with $\mathrm{pH} 7.4$ at a 1:10 ratio. The homogenate was centrifuged $(4000 \times g$, for $30 \mathrm{~min}$ ) and the supernatant was stored at $-20 \mathrm{C}$. The supernatant was used for the estimation of superoxide dismutase (SOD), as described by (Nishikimi et al., 1972), and glutathione (GSH) content, as described by (Prins and Loose, 1969). For determination of lipid peroxidation products MDA (malondialdehyde), lung tissue was homogenized with ice-cold $\mathrm{KCl}$ solution, as described by (Stroev and Makarova, 1989; Esterbauer and Cheeseman, 1990).

\subsection{Statistical analysis}

Data are presented as mean \pm S.E. of the mean. Statistical differences between means were calculated using one way ANOVA, analysis was performed with SPSS 15.0 software package (SPSS Inc., Chicago, IL, USA) Differences were considered significant at $\mathrm{p}<0.05$.

\section{Results}

\subsection{The effect of $O V A$ and $L$. dentata extract on Concentrations of $\operatorname{IgE}$ and $\operatorname{Ig} G$ in serum}

Concentrations of IgE were elevated in OVA and OVA+EXT groups as compared with control group, but the administration of extract reduced the concentrations of IgE when compared with OVA group. In addition, there were no significant changes in IgG concentrations in all groups (Table 1).

\subsection{The effect of $O V A$ and $L$. dentata extract on the content of Triglycerides and total Cholesterol in serum}

The treatment with OVA caused a significant increase in content of Triglycerides and total Cholesterol in serum when compared with control group (Table 2). In addition, L. dentata extract showed a decrease in serum Triglycerides content and total Cholesterol as compared to OVA group (Table 2).

\subsection{The effect of $O V A$ and $L$. dentata extract on the content of total protein, albumin, globulin, and the concentration of urea and creatinine in serum}

There were no significant differences in the content of total protein, albumin, globulin and concentration of urea and creatinine in serum among the groups (Table 2).

\subsection{The effect of OVA and L. dentata extract on Glucose level in serum}

OVA-sensitization and challenge group caused a significant increase in Glucose level. However, L. dentata extract alone or with OVA-sensitized and challenged showed a significant decrease in glucose level (Table 2).

\subsection{The effect of $O V A$ and $L$. dentata extract on the activity of ALT, AST, LDH and GGT in serum}

L. dentata extract did not affect the activities of serum enzymes ALT and AST. Also, there were no significant alteration in LDH activity in all experimental groups when compared to control group (Table 2). GGT activity decreased significantly in OVA- sensitized and challenged group. However, the activity of GGT in serum was not altered in OVA+ EXT and L. dentata extract groups when compared to control group (Table 2).

\subsection{The effect of L. dentata extract on the products of lipid peroxidation in lung tissues of immunized and challenged Guinea Pigs}

Tissue Malondialdehyde (MDA) was significantly increased in OVA group when compared with control group. In OVA+EXT group, MDA was decreased by L. dentata extract administration when compared with OVA group (Table 3)

Table 1. The effect of OVA and L. dentata extract on Concentrations of IgE and IgG in serum.

\begin{tabular}{cccccc}
\hline \multirow{2}{*}{ Treatment } & \multicolumn{5}{c}{ Groups } \\
\cline { 2 - 6 } & \multicolumn{1}{c}{ Control } & \multicolumn{1}{c}{ Tween80 } & \multicolumn{1}{c}{ OVA } & \multicolumn{1}{c}{ EXT } & OVA+EXT \\
\hline IgE concentration $(\mathrm{ng} / \mathrm{ml})$ & $0.116 \pm 0.002$ & $0.13 \pm 0.004$ & $0.18 \pm 0.008 \mathrm{a}$ & $0.11 \pm 0.004$ & $0.15 \pm 0.02 \mathrm{ab}$ \\
IgG concentration $(\mathrm{g} / \mathrm{L})$ & $2.66 \pm 0.14$ & $2.80 \pm 0.06$ & $2.68 \pm 0.08$ & $2.68 \pm 0.05$ & $2.56 \pm 0.02$ \\
\hline
\end{tabular}

Values are expressed as Means \pm SE. $(n=5)$. a Significant compared to the control group $(\mathrm{p}<0.05)$; b Significant compared to the OVA group $(\mathrm{p}<0.05)$. Ovalbumin (OVA), Lavendula dentata extract (EXT). 


\subsection{The effect of OVA and L. dentata extract on the activity of SOD and GSH content in lung tissue}

The results showed a decrease in SOD and GSH content in OVA-sensitized and challenged group as compared to control group. In addition, in OVA+ extract group, SOD activity was similar to control group, and GSH content was increased when compared to OVA group (Table 3).

\subsection{The effect of $O V A$ and $L$. dentata extract on total cell count in blood}

OVA and OVA+EXT groups showed a significant increase in WBC count as compared to control group, although the results did not show any change in the number of RBC, blood platelets, Hgb content and Hct percentage in all groups (Table 4).

\section{Discussion}

Seasonal allergy, food allergy, asthma and anaphylaxis cause immediate hypersensitivity reaction, and $\operatorname{IgE}$ is one of the main mediators (Corry and Kheradmand, 1999). Total serum IgE level is related with severity of these allergic diseases (Coffman et al., 1989), which strongly supports the specificity of the local IgE response in the bronchi for allergen (Wilson et al., 2002). The results showed Significant increase in the concentration of IgE after treatment with OVA, and the same results have been reported in many studies (Ayoub et al., 2003; Bao et al., 2007; Chang et al., 2009; Yano et al., 2007; Yang et al., 2008), early asthmatic response caused by elevated $\operatorname{IgE}$ induced the degranulation of mast cells by cross-linkage of allergen-specific IgE, and this process is a

Table 2. The effect of OVA and L. dentata extract on biochemical blood parameters levels in serum.

\begin{tabular}{cccccc}
\hline \multirow{2}{*}{ Treatment } & \multicolumn{5}{c}{ Groups } \\
\cline { 2 - 6 } & Control & Tween80 & OVA & EXT & OVA+EXT \\
\hline Triglycerides $(\mathrm{mg} / 100 \mathrm{ml})$ & $0.71 \pm 0.05$ & $1.03 \pm 0.09$ & $1.42 \pm 0.29 \mathrm{a}$ & $0.54 \pm 0.05$ & $0.91 \pm 0.08 \mathrm{~b}$ \\
Total Cholesterol $(\mathrm{mg} / 100 \mathrm{ml})$ & $0.65 \pm 0.09$ & $0.88 \pm 0.09$ & $0.97 \pm 0.14 \mathrm{a}$ & $0.63 \pm 0.03$ & $0.52 \pm 0.06 \mathrm{~b}$ \\
Total Protein $(\mathrm{g} / \mathrm{L})$ & $64.6 \pm 2.5$ & $63.2 \pm 0.3$ & $68.9 \pm 2.3$ & $64.4 \pm 1.4$ & $62.9 \pm 2.2$ \\
Albumin $(\mathrm{g} / \mathrm{L})$ & $34.8 \pm 0.36$ & $33.49 \pm 1.07$ & $33.8 \pm 1.05$ & $33.03 \pm 0.52$ & $33.07 \pm 0.78$ \\
Globulin (g/L) & $32.19 \pm 2.09$ & $32.6 \pm 0.22$ & $35.1 \pm 0.96$ & $30.7 \pm 0.74$ & $33.2 \pm 1.1$ \\
Urea (mg/100ml) & $1.72 \pm 0.40$ & $1.73 \pm 0.40$ & $1.6 \pm 0.34$ & $1.3 \pm 0.19$ & $1.5 \pm 0.09$ \\
Creatinine (mg/100ml) & $1.47 \pm 0.11$ & $1.52 \pm 0.11$ & $1.66 \pm 0.14$ & $1.58 \pm 0.13$ & $1.80 \pm 0.24$ \\
Glucose level (mg/100ml) & $141.1 \pm 4.29$ & $152.4 \pm 16.7$ & $169.4 \pm 7.24 \mathrm{a}$ & $76.80 \pm 1.06 \mathrm{a}$ & $98.03 \pm 2.86 \mathrm{ab}$ \\
ALT activity (U/L) & $82.99 \pm 0.68$ & $82.35 \pm 2.50$ & $83.45 \pm 2.10$ & $82.12 \pm 1.83$ & $83.22 \pm 1.73$ \\
AST activity (U/L) & $150.39 \pm 2.27$ & $147.23 \pm 2.23$ & $147.50 \pm 3.18$ & $149.29 \pm 3.17$ & $145.15 \pm 2.38$ \\
GGT activity (U/L) & $28.45 \pm 0.93$ & $28.69 \pm 1.39$ & $24.58 \pm 1.45 \mathrm{a}$ & $25.02 \pm 0.85$ & $25.41 \pm 1.71$ \\
LDH activity (U/L) & $235.7 \pm 5.18$ & $238.21 \pm 3.86$ & $239.6 \pm 3.70$ & $233.13 \pm 6.64$ & $245.72 \pm 10.88$ \\
\hline
\end{tabular}

Values are expressed as Means \pm SE. $(n=5)$. a Significant compared to the control group $(\mathrm{p}<0.05)$; $b$ Significant compared to the OVA group ( $\mathrm{p}<0.05)$. Ovalbumin (OVA); Lavendula dentata extract (EXT); Alanine aminotransferase (ALT); Aspartate aminotransferase (AST); gamma-glutamyl-transferase (GGT) and lactate dehydrogenase (LDH).

Table 3. The effect of OVA and L. dentata extract on oxidative stress biomarkers in lung tissues of male of male guinea pigs.

\begin{tabular}{cccccc}
\hline \multirow{2}{*}{ Treatment } & \multicolumn{5}{c}{ Groups } \\
\cline { 2 - 6 } & Control & Tween80 & OVA & EXT & OVA+EXT \\
\hline MDA & $0.77 \pm 0.029$ & $1.92 \pm 0.37$ & $42.7 \pm 1.66 \mathrm{a}$ & $4.8 \pm 1.49$ & $32.46 \pm 2.09 \mathrm{ab}$ \\
$(\mathrm{nmol} / 100 \mathrm{ml})$ & & & & & \\
$\mathrm{SOD}(\mathrm{U} / \mathrm{g})$ & $7558.7 \pm 248.3$ & $7540.76 \pm 77.59$ & $6776.3 \pm 27.94 \mathrm{a}$ & $7792.6 \pm 151.72$ & $7432.63 \pm 438.27$ \\
$\mathrm{GSH}(\mathrm{mg} / \mathrm{g})$ & $0.069 \pm 0.004$ & $0.069 \pm 0.002$ & $0.013 \pm 0.001 \mathrm{a}$ & $0.055 \pm 0.005$ & $0.037 \pm 0.004 \mathrm{ab}$ \\
\hline
\end{tabular}

Values are expressed as Means \pm SE. $(n=5)$. a Significant compared to the control group $(\mathrm{p}<0.05)$; b Significant compared to the OVA group $(\mathrm{p}<0.05)$. Ovalbumin (OVA); Lavendula dentata extract (EXT); MDA (malondialdehyde); glutathione $(\mathrm{GSH})$; superoxide dismutases (SOD).

Table 4. The effect of OVA and L. dentata extract on total cell count in blood.

\begin{tabular}{cccccc}
\hline \multirow{2}{*}{ Treatment } & \multicolumn{5}{c}{ Groups } \\
\cline { 2 - 6 } & Control & Tween80 & OVA & EXT & OVA+EXT \\
\hline RBCs $\left(10^{6} / \mathrm{mm}^{3}\right)$ & $7.80 \pm 0.07$ & $8.21 \pm 0.17$ & $7.88 \pm 0.08$ & $7.14 \pm 0.42$ & $7.33 \pm 0.49$ \\
WBCs $\left(10^{3} / \mathrm{mm}^{3}\right)$ & $8.78 \pm 0.09$ & $7.70 \pm 0.22$ & $12.14 \pm 0.27 \mathrm{a}$ & $9.16 \pm 0.79$ & $11.42 \pm 0.57 \mathrm{a}$ \\
PLT $\left(10^{3} / \mathrm{mm}^{3}\right)$ & $338.4 \pm 5.97$ & $389.6 \pm 26.34$ & $363 \pm 16.94$ & $403.8 \pm 28.76$ & $377.4 \pm 39.65$ \\
Hgb $(\mathrm{g} / 100 \mathrm{ml})$ & $17.84 \pm 0.17$ & $18.88 \pm 0.10$ & $17.80 \pm 0.15$ & $17.20 \pm 0.67$ & $17.12 \pm 0.79$ \\
RBCs $\left(10^{6} / \mathrm{mm}^{3}\right)$ & $7.80 \pm 0.07$ & $8.21 \pm 0.17$ & $7.88 \pm 0.08$ & $7.14 \pm 0.42$ & $7.33 \pm 0.49$ \\
\hline
\end{tabular}

Values are expressed as Means \pm SE. $(\mathrm{n}=5$ ); a Significant compared to the control group $(\mathrm{p}<0.05)$. Ovalbumin (OVA); Lavendula dentata extract (EXT); red blood cells (RBC); White blood cells (WBC); Blood platelets (PLT). 
key step in developing asthmatic responses (Chang et al., 2009). Elevated IgE levels in serum is an indication of Th2 immune response (Bao et al., 2007). The treatment with Lavender toothed extract led to a significant decrease in the level of $\operatorname{IgE}$ when compared to OVA group, which indicates that Lavender toothed extract has anti-asthma effect by lowering IgE levels, the release of histamine and TNF-alpha is induced by IgE (Kim et al., 2006). In serum and extravascular spaces, IgG is the main Ig (Schroeder Junior and Cavacini, 2010). There was no significant change in IgG levels in all groups. Wilson et al. (2002) reported that there was no increase in allergen-specific IgG, and this confirms the class-specificity of the response, which indicates the important role of the local $\operatorname{IgE}$ response to allergen (Wilson et al., 2002).

A clinical study has reported that hypercholesterolemia is a possible risk factor for asthma (Al-Shawwa et al., 2006). Human and animal studies reported that hypercholesterolemia is related with high levels of inflammation-sensitive plasma proteins (Engström et al., 2002), it's also associated with elevated expression of pro-inflammatory genes, cellular adhesion molecules, and pro-inflammatory cytokines (Scalia et al., 1998; Stokes et al., 2002), therefore, lipid profiles in serum might be related with immunological responses during inflammation (Chang et al., 2009). OVA-sensitization and challenge caused a significant increase in the content of Cholesterol and triglycerides, and these studies (Al-Shawwa et al., 2006; Chang et al., 2009) showed similar results. Yeh and Huang (2004) stated that allergic pulmonary inflammation is significantly associated with serum cholesterol levels in sensitized male C57BL6 mice with ovalbumin. Although the treatments with Lavender toothed extract caused a significant decrease in triglycerides and total cholesterol, the results of this study confirmed the hypolipidemic effects of Lavender toothed extract in allergic asthma model.

Malondialdehyde (MDA) is an end-product of peroxidation of cell membrane lipids caused by oxygen-derived free radicals, and is considered a reliable marker of inflammatory tissue damage. MDA is a marker of free radical-mediated inflammatory damage, (Masini et al., 2005), and the amount of MDA in lungs determines the level of lipid peroxides (Abe et al., 2006). In this study, MDA levels increased significantly in the lungs after OVA challenge in comparison with control group. Airway inflammation and hyper-reactivity in asthma are likely to involve oxidative stress to the lungs. Excess production of ROS by immune cells may have an important role in airway injury in asthma (Dworski, 2000; Talati et al., 2006). Administration of extract showed significantly-reduced MDA in guinea pig's lung homogenates, suggesting potential antioxidant effects, this is in line with (Hancianu et al., 2013; Hui et al., 2010; Wang et al., 2012). Hohmann et al. (1999) suggests that Phenolic components in lavender toothed extracts were evaluated for antioxidant activity (Hohmann et al., 1999). The results showed that OVA dose did not cause any significant changes in the total protein content, albumin and globulin in serum, and similar results have been reported in many studies (Picado et al., 1999; Orozco-Levi et al., 2001; Wilson et al., 2002), which indicates that there is a balance in protein metabolism processes. The treatment with extract showed no changes in the total protein content, albumin and globulin.

In this study, creatinine and urea concentrations were not affected by OVA treatment, the same results have been reported in different studies (Cimerman et al., 2000; Laing et al., 2000; Mahajan et al., 2009; Wiser et al., 2008). Also, treatment with extract was in normal concentration of creatinine and urea, which indicates normal kidney function (Fox, 2016).

OVA sensitization and challenge results showed a significant increase in glucose level, and this is in line with (Gulcan et al., 2009). The disturbance of glucose metabolism caused by inflammation-induced insulin resistance may occur in asthmatic patients, and this phenomenon may increase the risk of diabetes (Gulcan et al., 2009). Also, the results have shown a significant decrease in glucose level of the extract treatment, which indicates that it has a hypoglycemic activity (Gamez et al., 1988; Sosa et al., 2005)

The lungs are constantly exposed to many atmospheric pollutants, such as cigarette smoke, ozone, and nitrogen dioxide, and is also at risk from oxidant injury by inhalation of high concentrations of oxygen. It is a major target for circulating oxidants and xenobiotics, due to its large endothelial surface area. Hence, the lungs are one of the major sources for GSH storage (6.1-17.5 nmol/mg lung), which accounts for $90 \%$ of intra-cellular non-protein thiols (Meister, 1991). Most intra-cellular glutathione occurs as reduced GSH depending on the cell type (Meister and Anderson, 1983).

GSH concentration varies throughout the respiratory tract, it is lower in nasal cavity lining fluid than in alveoli lining fluid. GSH levels in the epithelial lining fluid of the lungs are approximately 100 times higher than that of plasma (Cross et al., 1994). Alteration in alveolar and lung GSH metabolism are widely recognized as a central feature of many inflammatory lung diseases such as asthma (Lee et al., 2006). In this study, asthma model, OVA sensitization and challenge caused a significant decrease in GSH level, and these results are in line with (Kloek et al., 2010; Lee et al., 2006). Lawrence et al. (2000) suggests that the role of GSH in immune regulation remains to be determined, and several studies have demonstrated a correlation between decreased GSH and immune suppression (Dröge et al., 1986; Yim et al., 1994). Also, the results of this study showed that levels of GSH were increased when treated with lavender toothed extract, which indicates the effectiveness of lavender plant as an antioxidant (Chu and Kemper, 2001; Wang et al., 2012). Lopez et al. (2007) deduced that polyphenol has the highest radical scavenger capacity which shows the antioxidant activity of these compounds. In this study, we observed a significant decrease in the activity of GGT enzyme of the OVA group. However, there were no changes in the 
activity of GGT enzyme of the extract group. GGT enzyme is one of the most widely used clinical indicators of tissue damage, and it is an important enzyme in metabolism of extracellular glutathione. It is also a key to glutathione homeostasis because it provides substrates for glutathione synthesis (Heisterkamp et al., 2008).

The lung contains high levels of antioxidant resources that prevent airway-borne oxidant injury. SOD is an essential antioxidant that catalyzes superoxide radical to hydrogen peroxide (Fattman et al., 2003). Comhair et al. (2005) study hypothesized that impaired SOD antioxidant defense is a primary event in the pathophysiology of hyperresponsiveness and remodeling which induces apoptosis and shedding of airway epithelial cells. These results show a significant decrease in SOD activity after OVA sensitization and challenge, this is consistent with (Comhair et al., 2005; Du et al., 1998; Masini et al., 2005). These findings support a link between SOD activity and physiological parameters of asthma severity (Comhair et al., 2005). SOD enzymes are a primary component of the antioxidant defense system that limits lung injury from oxygen radicals, but they are prone to inactivation by superoxide radicals (Bowler and Crapo, 2002). In fact, chronic asthma patients have reduced levels of SOD activity in cells and epithelial lining fluid of lungs as compared to healthy control subjects (Barnes, 1990). However, SOD levels were normal after treatment with lavender toothed extract as compared to control group. Lavender is reported to have antioxidant effects.

In this study, both ALT and AST levels were normal in plasma, which confirms absence of liver toxicity effects. ALT and AST are known as indicators of hepatocellular damage (Yang et al., 2008). LDH is a cytoplasmic enzyme present in essentially all major organ systems, and the extracellular appearance of LDH has been used to detect cell damage or cell death (Click Junior, 1969). Thus, measurement of LDH activity is a sensitive indicator of lung damage or inflammation (Drent et al., 1996). This study shows that OVA dose did not cause any significant change in LDH activity, also the administration of extract showed a normal activity of LDH in plasma.

In asthma model, OVA sensitization and challenge marked a significant increase in WBC count as compared to the control group. Total WBC count increased because of increased differential cell counts in blood (Mahajan et al., 2009), such as eosinophils, neutrophils and basophil (Umetsu and DeKruyff, 2010). This study showed that treatment with extract results in a significant decrease in WBC count when compared with OVA group, which means the extract has anti-inflammatory effects (Hajhashemi et al., 2003; Shubina et al., 1990; Sosa et al., 2005).

\section{Conclusions}

These findings confirm the potential effects of the aromatic plant Lavandula dentate extract, it has an anti-asthma, anti-inflammatory, hypolipidemic, antioxidant and hypoglycemic activity,

\section{Acknowledgements}

This Article contains the results and findings of a research project that is funded by King Abdul-Aziz City for Science and Technology (KACST) Grant No. (GSP-17-29).

\section{References}

ABE, M., HAYASHI, Y., MURAI, A., SHIBATA, K., SAKATA, N., IGARASHI, R., KATSURAGI, T. and TANAKA, K., 2006. Effects of inducible nitric oxide synthase inhibitors on asthma depending on administration schedule. Free Radical Biology \& Medicine, vol. 40, no. 6, pp. 1083-1095. http://dx.doi.org/10.1016/j. freeradbiomed.2005.10.057. PMid:16540403.

ALGIERI F, RODRIGUEZ-NOGALES A, VEZZA T, GARRIDOMESA J, GARRIDO-MESA N, UTRILLA MP, GONZÁLEZTEJERO MR, CASARES-PORCEL M, MOLERO-MESA J, DEL MAR CONTRERAS M, SEGURA-CARRETERO A, PÉREZ-PALACIO J, DIAZ C, VERGARA N, VICENTE F, RODRIGUEZ-CABEZAS ME AND GALVEZ J. 2016. Antiinflammatory activity of hydroalcoholic extracts of Lavandula dentata L. and Lavandula stoechas L. Journal of ethnopharmacology. vol. 190, pp. 142-158.

ALI, B., AL-WABEL, N.A., SHAMS, S., AHAMAD, A., KHAN, S.A. and ANWAR, F., 2015. Essential oils used in aromatherapy: A systemic review. Asian Pacific Journal of Tropical Biomedicine, vol. 5, no. 8, pp. 601-611. http://dx.doi. org/10.1016/j.apjtb.2015.05.007.

AL-MUSAYEIB, N.M., MOTHANA, R.A., MATHEEUSSEN, A., COS, P. and MAES, L., 2012. In vitro antiplasmodial, antileishmanial and antitrypanosomal activities of selected medicinal plants used in the traditional Arabian Peninsular region. BMC Complementary and Alternative Medicine, vol. 12, no. 6, pp. 441-442. PMid:22520595.

AL-SHAWWA, B., AL-HUNITI, N., TITUS, G. and ABUHASAN, M., 2006. Hypercholesterolemia is a potential risk factor for asthma. The Journal of Asthma, vol. 43, no. 3, pp. 231-233. http://dx.doi.org/10.1080/02770900600567056. PMid:16754527.

AYOUB, M., LALlouette, P., SÜtTERlin, B.W., BESSLER, W.G., HUBER, M. and MITTENBÜHLER, K., 2003. Modulation of the Th1/Th2 bias by an immunoglobulin histamine complex in the ovalbumin allergy mouse model. International Immunopharmacology, vol. 3, no. 4, pp. 523-539. http://dx.doi. org/10.1016/S1567-5769(03)00031-6. PMid:12689657.

BAO, Z., LIM, S., LIAO, W., LIN, Y., THIEMERMANN, C., LEUNG, B.P. and WONG, W.F., 2007. Glycogen synthase kinase- $3 \beta$ inhibition attenuates asthma in mice. American Journal of Respiratory and Critical Care Medicine, vol. 176, no. 5, pp. 431-438. http://dx.doi.org/10.1164/rccm.200609-1292OC. PMid:17556716.

BARNES, P.J., 1990. Reactive oxygen species and airway inflammation. Free Radical Biology \& Medicine, vol. 9, no. 3, pp. 235-243. http://dx.doi.org/10.1016/0891-5849(90)90034-G. PMid:2272532.

BHATIA, D., GUPTA, M.K., BHARADWAJ, A., PATHAK, M., KATHIWAS, G. and SINGH, M. 2008. Anti-diabetic activity of Centratherum anthelminticum kuntze on alloxan induced diabetic rats. Pharmacologyonline, vol. 3, no. 5, pp. 1-5.

BOWLER, R.P. and CRAPO, J.D., 2002. Oxidative stress in allergic respiratory diseases. The Journal of Allergy and Clinical 
Immunology, vol. 110, no. 3, pp. 349-356. http://dx.doi.org/10.1067/ mai.2002.126780. PMid:12209079.

BÜYÜKOKUROĞLU, M.E., GEPDIREMEN, A., HACIMÜFTÜOĞLU, A. and OKTAY, M., 2003. The effects of aqueous extract of Lavandula angustifolia flowers in glutamateinduced neurotoxicity of cerebellar granular cell culture of rat pups. Journal of Ethnopharmacology, vol. 84, no. 1, pp. 91-94. http:// dx.doi.org/10.1016/S0378-8741(02)00286-6. PMid:12499081.

CHANG, H.H., CHEN, C.S. and LIN, J.Y., 2009. Dietary perilla oil lowers serum lipids and ovalbumin-specific IgG1, but increases total IgE levels in ovalbumin-challenged mice. Food and Chemical Toxicology, vol. 47, no. 4, pp. 848-854. http://dx.doi. org/10.1016/j.fet.2009.01.017. PMid:19271319.

CHU CJ, KEMPER KJ., 2001. Lavender (Lavandula spp.). Longwood Herbal Task Force, vol. 32.

CIMERMAN, N., BRGULJAN, P.M., KRAŠOVEC, M., ŠUŠKOVIČ, S. and KOS, J., 2000. Serum cystatin C, a potent inhibitor of cysteine proteinases, is elevated in asthmatic patients. Clinica Chimica Acta, vol. 300, no. 1, pp. 83-95. http://dx.doi. org/10.1016/S0009-8981(00)00298-9. PMid:10958865.

CLICK JUNIOR, J.H., 1969. Serum lactate dehydrogenase isoenzyme and total lactate dehydrogenase values in health and disease, and clinical evaluation of these tests by means of discriminant analysis. American Journal of Clinical Pathology, vol. 52, no. 3, pp. 320-328. http://dx.doi.org/10.1093/ajcp/52.3.320. PMid:5805997.

COFFMAN, R.L., SEYMOUR, B.W., HUDAK, S., JACKSON, J. and RENNICK, D., 1989. Antibody to interleukin-5 inhibits helminth-induced eosinophilia in mice. Science, vol. 245, no. 4915, pp. 308-310. http://dx.doi.org/10.1126/science. 2787531.

COMHAIR, S.A., XU, W., GHOSH, S., THUNNISSEN, F.B., ALMASAN, A., CALHOUN, W.J., JANOCHA, A.J., ZHENG, L., HAZEN, S.L. and ERZURUM, S.C.COMHAIR, S.A., XU, W., GHOSH, S., THUNNISSEN, F.B., ALMASAN, A., CALHOUN, W.J. and ERZURUM, S.C., 2005. Superoxide dismutase inactivation in pathophysiology of asthmatic airway remodeling and reactivity. American Journal of Pathology, vol. 166 , no. 3, pp. 663-674. http://dx.doi.org/10.1016/S00029440(10)62288-2. PMid:15743779.

CORRY, D.B. and KHERADMAND, F., 1999. Induction and regulation of the IgE response. Nature, vol. 402, pp. 18-23."http:// dx.doi.org/10.1038/35037014.

CROSS, C.E., VAN DER VLIET, A., O'NEILL, C.A., LOUIE, S. and HALLIWELL, B., 1994. Oxidants, antioxidants, and respiratory tract lining fluids. Environmental Health Perspectives, vol. 102, suppl. 10, pp. 185-191. PMid:7705296.

DRENT, M., COBBEN, N.A., HENDERSON, R.F., WOUTERS, E.F. and VAN DIEIJEN-VISSER, M., 1996. Usefulness of lactate dehydrogenase and its isoenzymes as indicators of lung damage or inflammation. The European Respiratory Journal, vol. 9, no. 8, pp. 1736-1742. http://dx.doi.org/10.1183/09031936.96.0908 1736. PMid:8866602.

DRÖGE, W., POTTMEYER-GERBER, C., SCHMIDT, H. and NICK, S., 1986. Gluthatione Augments the Activation of Cytotoxic T Lymphocytes in vivo. Immunobiology, vol. 172, no. 1-2, pp. 151-156. http://dx.doi.org/10.1016/S0171-2985(86)800614. PMid:3490430.

DU, J., CUI, D. and GUO, Y., 1998. Detection of ET-1, TNFalpha, oxidative radicals in sera of asthmatics and in sera and lung tissue of asthmatic guinea pigs. Zhonghua Jie He He Hu Xi Za Zhi, vol. 21, no. 5, pp. 293-296. PMid:11326955.

DUKE, J.A., 1989. CRC Handbook of Medicinal Herbs. Boca Raton: CRC Press, 273 p.

DWORSKI, R., 2000. Oxidant stress in asthma. Thorax, vol. 55, no. 90002, suppl. 2, pp. S51-S53. http://dx.doi.org/10.1136/ thorax.55.suppl_2.S51.PMid:10992559.

ELOVSSON, S., SMAILAGIC, A., ERJEFALT, I., ZACKRISSON, C., ERIKSSON, C. and WANG, X., 2005. Evaluation of nasal barrier dysfunction at acute-and late-phase reactions in a guinea pig model of allergic rhinitis. Vascular Pharmacology, vol. 43, no. 4, pp. 267-276. http://dx.doi.org/10.1016/j.vph.2005.08.016. PMid:16257271.

ENGSTRÖM, G., LIND, P., HEDBLAD, B., STAVENOW, L., JANZON, L. and LINDGÄRDE, F., 2002. Effects of cholesterol and inflammation-sensitive plasma proteins on incidence of myocardial infarction and stroke in men. Circulation, vol. 105, no. 22, pp. 2632-2637. http://dx.doi.org/10.1161/01.CIR.0000017327.69909. FF. PMid:12045169.

ESTERBAUER, H. and CHEESEMAN, K.H., 1990. Determination of aldehydic lipid peroxidation products: malonaldehyde and 4-hydroxynoneal. Methods in Enzymology, vol. 186, pp. 407-421. http://dx.doi.org/10.1016/0076-6879(90)86134-H. PMid:2233308.

EVANS, W.C., 1989. Trease and Evans' Pharmacognosy. 13th ed. London: Bailliere Tindall, pp. 433-434.

FATTMAN, C.L., SCHAEFER, L.M. and OURY, T.D., 2003. Extracellular superoxide dismutase in biology and medicine. Free Radical Biology \& Medicine, vol. 35, no. 3, pp. 236-256. http:// dx.doi.org/10.1016/S0891-5849(03)00275-2. PMid:12885586.

FOX, S.I., 2016. Human physiology. New York: McGraw-Hill.

GAMEZ, M.J., JIMENEZ, J., RISCO, S. and ZARZUELO, A., 1987. Hypoglycemic activity in various species of genus Lavandula. Part I: Lavandula stoechas L. and Lavandula multifida L. Die Pharmazie, vol. 42, no. 10, pp. 706-707. PMid:3438332.

GAMEZ, M.J., ZARZUELO, A., RISCO, S., UTRILLA, P. and JIMENEZ, J., 1988. Hypoglycemic activity in various species of the genus Lavandula. II: Lavandula dentata and Lavandula latifolia. Die Pharmazie, vol. 43, no. 6, pp. 441-442. PMid:3212035.

GHELARDini, C., GALEOTTI, N., SALVATORE, G. and MAZZANTI, G., 1999. Local anaesthetic activity of the essential oil of Lavandula angustifolia. Planta Medica, vol. 65, no. 8, pp. 700-703. http://dx.doi.org/10.1055/s-1999-14045. PMid:10630108.

GILANI, A.H., AZIZ, N., KHAN, M.A., SHAHEEN, F., JABEEN, Q., SIDDIQUI, B.S. and HERZIG, J.W., 2000. Ethnopharmacological evaluation of the anticonvulsant, sedative and antispasmodic activities of Lavandula stoechas L. Journal of Ethnopharmacology, vol. 71, no. 1-2, pp. 161-167. http://dx.doi. org/10.1016/S0378-8741(99)00198-1. PMid:10904159.

GLOBAL INITIATIVE FOR ASTHMA - GINA, 2014 [viewed 4 June 2014]. GINA Report, Global Burden of Asthma. Available from: www.ginasthma.org.

GULCAN, E., BULUT, I., TOKER, A. and GULCAN, A., 2009. Evaluation of glucose tolerance status in patients with asthma bronchiale. The Journal of Asthma, vol. 46, no. 2, pp. 207-209. http://dx.doi.org/10.1080/02770900802627302. PMid:19253132.

HAJHASHEMI, V., GHANNADI, A. and SHARIF, B., 2003. Anti-inflammatory properties of the leaf extracts and essential oil of Lavandula angustifolia Mill. Journal of Ethnopharmacology, 
vol. 89 , no. 1, pp. 67-71. http://dx.doi.org/10.1016/S03788741(03)00234-4. PMid:14522434.

HANCIANU, M., CIOANCA, O., MIHASAN, M. and HRITCU, L., 2013. Neuroprotective effects of inhaled lavender oil on scopolamine-induced dementia via anti-oxidative activities in rats. Phytomedicine, vol. 20, no. 5, pp. 446-452. http://dx.doi. org/10.1016/j.phymed.2012.12.005. PMid:23351960.

HEISTERKAMP, N., GROFFEN, J., WARBURTON, D. and SNEDDON, T.P., 2008. The human gamma-glutamyltransferase gene family. Human Genetics, vol. 123, no. 4, pp. 321-332. http:// dx.doi.org/10.1007/s00439-008-0487-7. PMid:18357469.

HOHMANN, J., ZUPKO, I., REDEI, D., CSANYI, M., FALKAY, G., MATHE, I. and JANICSÁK, G., 1999. Protective effects of the aerial parts of Salvia officinalis, Melissa officinalis and Lavandula angustifolia and their constituents against enzyme-dependent and enzyme-independent lipid peroxidation. Planta Medica, vol. 65, no. 6, pp. 576-578. http://dx.doi.org/10.1055/s-2006-960830. PMid:10532875.

HOLGATE, S.T., 2008. The airway epithelium is central to the pathogenesis of asthma. Allergology International, vol. 57, no. 1, pp. 1-10. http://dx.doi.org/10.2332/allergolint.R-07-154. PMid:18209502.

HUI, L., HE, L., HUAN, L., XIAOLAN L. and AIGUO Z. 2010 Chemical composition of lavender essential oil and its antioxidant activity and inhibition against rhinitis-related bacteria. African Journal of Microbiological Research, vol. 4, no. 4, pp. 309-313.

KIM, H.M. and CHO, S.H., 1999. Lavender oil inhibits immediatetype allergic reaction in mice and rats. The Journal of Pharmacy and Pharmacology, vol. 51, no. 2, pp. 221-226. http://dx.doi. org/10.1211/0022357991772178. PMid:10217323.

KIM, S.H., JUN, C.D., SUK, K., CHOI, B.J., LIM, H., PARK, S., LEE, S.H., SHIN, H.Y., KIM, D.K. and SHIN, T.Y., 2006. Gallic acid inhibits histamine release and pro-inflammatory cytokine production in mast cells. Toxicological Sciences, vol. 91, no. 1, pp. 123-131. http://dx.doi.org/10.1093/toxsci/kfj063. PMid:16322071.

KIRKHAM, P. and RAHMAN, I., 2006. Oxidative stress in asthma and COPD: antioxidants as a therapeutic strategy. Pharmacology \& Therapeutics, vol. 111, no. 2, pp. 476-494. http:// dx.doi.org/10.1016/j.pharmthera.2005.10.015. PMid:16458359.

KLOEK, J., MORTAZ, E., VAN ARK, I., LILLY, C.M., NIJKAMP, F.P. and FOLKERTS, G., 2010. Glutathione prevents the early asthmatic reaction and airway hyperresponsiveness in guinea pigs. Journal of Physiology and Pharmacology, vol. 61, no. 1, pp. 67-72. PMid:20228417.

LAING, I.A., HERMANS, C., BERNARD, A., BURTON, P.R., GOLDBLATT, J. and LE SOUËF, P.N., 2000. Association between plasma CC16 levels, the A38G polymorphism, and asthma. American Journal of Respiratory and Critical Care Medicine, vol. 161, no. 1, pp. 124-127. http://dx.doi.org/10.1164/ ajrccm.161.1.9904073. PMid:10619808.

LAWRENCE, B.P., WILL, Y., REED, D.J. and KERKVLIET, N.I., 2000. g-Glutamyltranspeptidase knockout mice as a model for understanding the consequences of diminished glutathione on $\mathrm{T}$ cell-dependent immune responses. European Journal of Immunology, vol. 30, no. 7, pp. 1902-1910. http://dx.doi.org/10.1002/15214141(200007)30:7<1902::AID-IMMU1902>3.0.CO;2-A. PMid:10940879.
LEE, K.S., KIM, S.R., PARK, S.J., MIN, K.H., LEE, K.Y., JIN, S.M., YOO, W.H. and LEE, Y.C., 2006. Antioxidant down-regulates interleukin-18 expression in asthma. Molecular Pharmacology, vol. 70, no. 4, pp. 1184-1193. http://dx.doi. org/10.1124/mol.106.024737. PMid:16822930.

LEUNG, A.Y. and FOSTER, S. 1996. Encyclopedia of common natural ingredients used in food, drugs and cosmetics. New York: Wiley, pp. 339-342.

LIS-BALCHIN, M. and HART, S., 1999. Studies on the mode of action of the essential oil lavender (Lavandula angustifolia $\mathrm{P}$. Miller). Phytotherapy Research, vol. 13, no. 6, pp. 540-542. http:// dx.doi.org/10.1002/(SICI)1099-1573(199909)13:6<540::AIDPTR523>3.0.CO;2-I. PMid:10479772.

LÓPEZ, V., AKERRETA, S., CASANOVA, E., GARCÍAMINA, J.M., CAVERO, R.Y. and CALVO, M.I., 2007. In vitro antioxidant and anti-rhizopus activities of Lamiaceae herbal extracts. Plant Foods for Human Nutrition, vol. 62, no. 4, pp. 151-155. http://dx.doi.org/10.1007/s11130-007-0056-6. PMid:17912643.

MAHAJAN, S.G., BANERJEE, A., CHAUHAN, B.F., PADH, H., NIVSARKAR, M. and MEHTA, A.A., 2009. Inhibitory effect of n-butanol fraction of Moringa oleifera Lam. seeds on ovalbumin-induced airway inflammation in a guinea pig model of asthma. International Journal of Toxicology, vol. 28, no. 6, pp. 519-527. http://dx.doi.org/10.1177/1091581809345165. PMid:19966143.

MARUYAMA, N., SEKIMOTO, Y., ISHIBASHI, H., INOUYE, S., OSHIMA, H., YAMAGUCHI, H. and ABE, S., 2005. Suppression of neutrophil accumulation in mice by cutaneous application of geranium essential oil. Journal of Inflammation, vol. 2, no. 1, pp. 1. http://dx.doi.org/10.1186/1476-9255-2-1. PMid:15813994.

MASINI, E., BANI, D., VANNACCI, A., PIERPAOLI, S., MANNAIONI, P.F., COMHAIR, S.A., XU, W., MUSCOLI, C., ERZURUM, S.C. and SALVEMINI, D., 2005. Reduction of antigen-induced respiratory abnormalities and airway inflammation in sensitized guinea pigs by a superoxide dismutase mimetic. Free Radical Biology \& Medicine, vol. 39, no. 4, pp. 520-531. http:// dx.doi.org/10.1016/j.freeradbiomed.2005.04.006. PMid:16043023.

MEISTER, A. and ANDERSON, M.E., 1983. Glutathione. Annual Review of Biochemistry, vol. 52, no. 1, pp. 711-760. http:// dx.doi.org/10.1146/annurev.bi.52.070183.003431. PMid:6137189.

MEISTER, A., 1991. Glutathione deficiency produced by inhibition of its synthesis and its reversal: applications in research and therapy. Pharmacology \& Therapeutics, vol. 51, no. 2, pp. 155-194. http://dx.doi.org/10.1016/0163-7258(91)90076-X. PMid: 1784629.

MISAKA, S., SATO, H., YAMAUCHI, Y., ONOUE, S. and YAMADA, S., 2009. Novel dry powder formulation of ovalbumin for development of COPD-like animal model: Physicochemical characterization and biomarker profiling in rats. European Journal of Pharmaceutical Sciences, vol. 37, no. 4-3, pp. 469-476. http:// dx.doi.org/10.1016/j.ejps.2009.04.002. PMid:19491038.

MURAKI, M., IWANAGA, T., HARAGUCHI, R., KUBO, H. and TOHDA, Y., 2008. Continued inhalation of lidocaine suppresses antigen-induced airway hyperreactivity and airway inflammation in ovalbumin-sensitized guinea pigs. International Immunopharmacology, vol. 8, no. 5, pp. 725-731. http://dx.doi. org/10.1016/j.intimp.2008.01.021. PMid:18387515.

NADEEM, A., MASOOD, A. and SIDDIQUI, N., 2008. Oxidant - antioxidant imbalance in asthma: scientific evidence, 
epidemiological data and possible therapeutic options. Therapeutic Advances in Respiratory Disease, vol. 2, no. 4, pp. 215-235. http://dx.doi.org/10.1177/1753465808094971. PMid:19124374.

NISHIKIMI, M., APPAJI, N. and YAGI, K., 1972. The occurrence of superoxide anion in the reaction of reduced phenazine methosulfate and molecular oxygen. Biochemical and Biophysical Research Communications, vol. 46, no. 2, pp. 849-854. http:// dx.doi.org/10.1016/S0006-291X(72)80218-3. PMid:4400444.

OMIDBAIGI, R., 2000. Production and Processing of Medicinal Plants, vol. 3. Mashhad: Astane Ghods Publications, pp. 106-122.

OROZCO-LEVI, M., LLORETA, J., MINGUELLA, J., SERRANO, S., BROQUETAS, J.M. and GEA, J., 2001. Injury of the human diaphragm associated with exertion and chronic obstructive pulmonary disease. American Journal of Respiratory and Critical Care Medicine, vol. 164, no. 9, pp. 1734-1739. http:// dx.doi.org/10.1164/ajrccm.164.9.2011150. PMid:11719318.

PARK, S.J., SHIN, W.H., SEO, J.W. and KIM, E.J., 2007. Anthocyanins inhibit airway inflammation and hyperresponsiveness in a murine asthma model. Food and Chemical Toxicology, vol. 45, no. 8, pp. 1459-1467. http://dx.doi.org/10.1016/j.fct.2007.02.013. PMid:17512652.

PICADO, C., DEULOFEU, R., LLEONART, R., AGUSTÍ, M., CASALS, E., QUINTÓ, L. and MULLOL, J., 1999. Lipid and protein metabolism in asthma. Effects of diet and corticosteroid therapy. Allergy, vol. 54, no. 6, pp. 569-575. http://dx.doi. org/10.1034/j.1398-9995.1999.00024.x. PMid:10435470.

PRINS, H.K. and LOOSE, J.A. 1969. Glutathione, In: J.J. YUNIS ed. Biochemical methods in red cell genetics chap. 40. London: Academic press, pp. 126-129.

RAHMAN, M.A., MOSSA, J.S., AL-SAID, M.S. and ALYAHYA, M.A., 2004. Medicinal plant diversity in the flora of Saudi Arabia 1: a report on seven plant families. Fitoterapia, vol. 75, no. 2, pp. 149-161. http://dx.doi.org/10.1016/j.fitote.2003.12.012. PMid:15030919.

RENAUD, E.N.C., CHARLES, D.J. and SIMON, J.E., 2001. Essential oil quantity and composition from 10 cultivars of organically grown lavender and lavandin. The Journal of Essential Oil Research, vol. 13, no. 4, pp. 269-273. http://dx.doi.org/10.1 080/10412905.2001.9699691.

ROH SS, KIM SH, LEE YC, SEO YB. Effects of radix adenophorae and cyclosporine A on an OVA-induced murine model of asthma by suppressing to T cells activity, eosinophilia, and bronchial hyperresponsiveness. Mediators of inflammation. 2008. vol. 2008, pp. 1-11.

SCALIA, R., APPEL 3RD, J.Z.. and LEFER, A.M., 1998. Leukocyte-endothelium interaction during the early stages of hypercholesterolemia in the rabbit. Arteriosclerosis, Thrombosis, and Vascular Biology, vol. 18, no. 7, pp. 1093-1100. http://dx.doi. org/10.1161/01.ATV.18.7.1093. PMid:9672069.

SCHROEDER JUNIOR, H.W. and CAVACINI, L., 2010. Structure and function of immunoglobulins. The Journal of Allergy and Clinical Immunology, vol. 125, no. 2, suppl. 2, pp. S41-S52. http://dx.doi.org/10.1016/j.jaci.2009.09.046. PMid:20176268.

SELGRADE, M.K., BLAIN, R.B., FEDAK, K.M. and CAWLEY, M.A., 2013. Potential risk of asthma associated with in utero exposure to xenobiotics. Birth Defects Research. Part C, Embryo Today, vol. 99, no. 1, pp. 1-13. http://dx.doi.org/10.1002/ bdrc.21028. PMid:23723168.
SHUBINA, L.P., SIURIN, S.A. and SAVCHENKO, V.M., 1990. Inhalations of essential oils in the combined treatment of patients with chronic bronchitis. Vrachebnoe delo, vol. 5, pp. 66-67.

SILVA, G.L., LUFT, C., LUNARDELLI, A., AMARAL, R.H., MELO, D.A., DONADIO, M.V., NUNES, F.B., DE AZAMBUJA, M.S., SANTANA, J.C., MORAES, C.M., MELLO, R.O., CASSEL, E., PEREIRA, M.A. and DE OLIVEIRA, J.R., 2015. MELO DA, Donadio MV, Mello RO. Antioxidant, analgesic and anti-inflammatory effects of lavender essential oil. Anais da Academia Brasileira de Ciências, vol. 87, no. 2, (suppl.), pp. 1397-1408. http://dx.doi.org/10.1590/0001-3765201520150056. PMid:26247152.

SOSA, S., ALTINIER, G., POLITI, M., BRACA, A., MORELLI, I. and DELLA LOGGIA, R., 2005. Extracts and constituents of Lavandula multifida with topical anti-inflammatory activity. Phytomedicine, vol. 12, no. 4, pp. 271-277. http://dx.doi. org/10.1016/j.phymed.2004.02.007. PMid:15898704.

STOKES, K.Y., COOPER, D., TAILOR, A. and GRANGER, D.N., 2002. Hypercholesterolemia promotes inflammation and microvascular dysfunction: role of nitric oxide and superoxide. Free Radical Biology \& Medicine, vol. 33, no. 8, pp. 1026-1036. http://dx.doi.org/10.1016/S0891-5849(02)01015-8. PMid:12374614.

STROEV, E.A. and MAKAROVA, V.G., 1989. Metabolism of Xenobiotics in Laboratory Manual in Biochemistry. Moscow: Mir Publishers, $178 \mathrm{p}$

TALATI, M., MEYRICK, B., PEEBLES JUNIOR, R.S., DAVIES, S.S., DWORSKI, R., MERNAUGH, R., MITCHELL, D., BOOTHBY, M., ROBERTS 2ND, L.J. and SHELLER, J.R., 2006. Oxidant stress modulates murine allergic airway responses. Free Radical Biology \& Medicine, vol. 40, no. 7, pp. 1210-1219. http://dx.doi.org/10.1016/j.freeradbiomed.2005.11.012. PMid:16545689.

UMETSU, D.T. and DEKRUYFF, R.H., 2010. Natural killer T cells are important in the pathogenesis of asthma: the many pathways to asthma. The Journal of Allergy and Clinical Immunology, vol. 125, no. 5, pp. 975-979. http://dx.doi.org/10.1016/j.jaci.2010.02.006. PMid:20338622.

VIJAYA, T., MAOULI, K.C. and RAO, S.D., 2009. Phytoresources as potential therapeutic agents for cancer treatment and prevention. Journal of Global Pharma Technology, vol. 1, no. 1

WANG, D., YUAN, X., LIU, T., LIU, L., HU, Y., WANG, Z. and ZHENG, Q., 2012. Neuroprotective activity of lavender oil on transient focal cerebral ischemia in mice. Molecules (Basel, Switzerland), vol. 17, no. 8, pp. 9803-9817. http://dx.doi. org/10.3390/molecules17089803. PMid:22895026.

WILSON, D.R., MERRETT, T.G., VARGA, E.M., SMURTHWAITE, L., GOULD, H.J., KEMP, M., HOOPER, J., TILL, S.J. and DURHAM, S.R., 2002. Increases in allergen-specific IgE in BAL after segmental allergen challenge in atopic asthmatics. American Journal of Respiratory and Critical Care Medicine, vol. 165, no. 1, pp. 22-26. http://dx.doi.org/10.1164/ajrccm.165.1.2010112. PMid:11779725.

WISER, J., ALEXIS, N.E., JIANG, Q., WU, W., ROBINETTE, C., ROUBEY, R. and PEDEN, D.B., 2008. In vivo $\gamma$-tocopherol supplementation decreases systemic oxidative stress and cytokine responses of human monocytes in normal and asthmatic subjects. Free Radical Biology \& Medicine, vol. 45, no. 1, pp. 40-49. http:// dx.doi.org/10.1016/j.freeradbiomed.2008.03.002. PMid:18405673.

WOOD, L.G., GIBSON, P.G. and GARG, M.L., 2003. Biomarkers of lipid peroxidation, airway inflammation and asthma. The 
European Respiratory Journal, vol. 21, no. 1, pp. 177-186. http:// dx.doi.org/10.1183/09031936.03.00017003a. PMid:12570126.

YANG, S.A., JEON, S.K., LEE, E.J., SHIM, C.H. and LEE, I.S., 2010. Comparative study of the chemical composition and antioxidant activity of six essential oils and their components. Natural Product Research, vol. 24, no. 2, pp. 140-151. http:// dx.doi.org/10.1080/14786410802496598. PMid:20077307.

YANG, S.T., WANG, X., JIA, G., GU, Y., WANG, T., NIE, H., GE, C., WANG, H. and LIU, Y., 2008. Long-term accumulation and low toxicity of single-walled carbon nanotubes in intravenously exposed mice. Toxicology Letters, vol. 181, no. 3, pp. 182-189. http://dx.doi.org/10.1016/j.toxlet.2008.07.020. PMid:18760340.

YANO, S., UMEDA, D., YAMASHITA, T., NINOMIYA, Y., SUMIDA, M., FUJIMURA, Y., YAMADA, K. and TACHIBANA,
H., 2007. Dietary flavones suppresses IgE and Th2 cytokines in OVA-immunized BALB/c mice. European Journal of Nutrition, vol. 46, no. 5, pp. 257-263. http://dx.doi.org/10.1007/s00394007-0658-7. PMid:17497073.

YEH, Y.F. and HUANG, S.L., 2004. Enhancing effect of dietary cholesterol and inhibitory effect of pravastatin on allergic pulmonary inflammation. Journal of Biomedical Science, vol. 11, no. 5, pp. 599-606. http://dx.doi.org/10.1007/BF02256124. PMid:15316134.

YIM, C.Y., HIBBS JUNIOR, J.B., MCGREGOR, J.R., GALINSKY, R.E. and SAMLOWSKI, W.E., 1994. Use of $\mathrm{N}$-acetyl cysteine to increase intracellular glutathione during the induction of antitumor responses by IL-2. Journal of Immunology, vol. 152 , no. 12 , pp. 5796-5805. PMid:8207209. 